\title{
Restless Legs Syndrome in Patients with Epilepsy Under Levetiracetam Monotherapy
}

\section{Levetirasetam Monoterapisi Altında Epilepsi Hastalarında Huzursuz Bacak Sendromu}

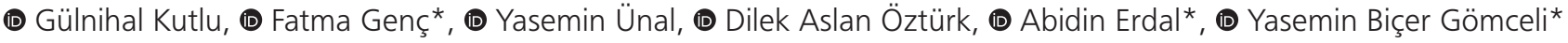 \\ Muğla Sıtkı Koçman University Faculty of Medicine, Department of Neurology, Muğla, Turkey \\ *University of Health Sciences, Antalya Training and Research Hospital, Clinic of Neurology, Antalya, Turkey
}

\begin{abstract}
Objective: Restless Legs syndrome (RLS) is a frequent neurological disease. Levetiracetam (LEV) is an effective and broad-spectrum anticonvulsant drug. The aim of this study is to investigate the frequency of RLS in patients diagnosed with epilepsy who took LEV monotherapy. Materials and Methods: Two neurologists were reviewed the files of 1680 patients, who were followed in epilepsy outpatient clinic. One hundred seven patients under LEV monotherapy for at least six months and 120 healthy controls were included in the study. The criteria for the International Restless Legs Syndrome Study Group were taken into consideration for the assessment of RLS.

Results: The mean age of patient group was $38.26 \pm 17.39$ years, while the mean age of healthy controls was $39.17 \pm 16.12$ years. There were no statistically significant differences in terms of age and sex between each two groups. The mean duration of LEV usage was 28.34 months. The LEV usage dose was between $500-3000 \mathrm{mg} /$ day. RLS was seen in 7 (5.83\%) healthy controls, whereas 4 patients (3.73\%) had RLS in patient group before LEV treatment. The symptom of RLS in two patients disappeared after LEV treatment started and this rate decreased to $1.87 \%$. The biochemical parameters were normal in all patient groups, after LEV treatment, peripheral neuropathy was detected in one patient whose symptoms were not relieved.

Conclusion: LEV may have therapeutic effect on RLS. It may be preferred especially in comorbid situations where epilepsy and RLS are seen together. Longitudinal and prospective studies are needed to manifest better the therapeutic effects of LEV on RLS.
\end{abstract}

Keywords: Levetiracetam, Restless Legs syndrome, treatment
Öz

Amaç: Huzursuz Bacak sendromu (HBS) sık görülen bir nörolojik hastalıktır. Levetirasetam (LEV) etkili ve geniş spektrumlu bir antiepileptik ilaçtır. Bu çalışmanın amacı epilepsi tanısı ile LEV monoterapisi alan hastalarda HBS sıklığını araştırmaktır.

Gereç ve Yöntem: Epilepsi polikliniğinde takip edilen 1680 hastanın dosyası iki nörolog tarafından gözden geçirildi. En az 6 aydır LEV monoterapisi alan 107 hasta ve 120 sağlıklı kontrol çalışmaya alındı. HBS değerlendirmesi için Uluslararası Huzursuz Bacak Sendromu Çalışma Grubu'nun kriterleri göz önüne alındı.

Bulgular: Sağlıklı kontrollerin ortalama yaşı $39,17 \pm 16,12$ yıl iken, hastaların ortalama yaşı $38,26 \pm 17,39$ yıldı. Her iki grup arasında yaş ve cinsiyet açısından istatistiksel anlamlı bir fark yoktu. Ortalama LEV kullanım süresi 28,34 aydı. LEV kullanım dozu 500-3000 mg/gün arasındaydı. HBS $7(\% 5,83)$ sağlıklı kontrolde görülürken, LEV tedavisi öncesi 4 hasta $(\% 3,73)$ HBS'ye sahipti. LEV tedavisine başladıktan sonra iki hastanın HBS semptomları kayboldu ve bu oran \%1,87'ye geriledi. Tüm hasta grubunun biyokimyasal parametreleri normaldi, LEV tedavisi sonrasında semptomları rahatlamayan bir hastada periferik nöropati saptandı.

Sonuç: LEV, HBS üzerinde tedavi edici etkiye sahip olabilir. Özellikle epilepsi ve $\mathrm{HBS}^{\prime}$ nin birlikte görüldüğü komorbid durumlarda tercih edilebilir. LEV'nin HBS üzerindeki tedavi edici etkilerini daha iyi ortaya koyabilmek için longitudinal ve prospektif çalışmalara ihtiyaç vardır.

Anahtar Kelimeler: Levetirasetam, Huzursuz Bacak sendromu, tedavi

\section{Introduction}

Restless legs syndrome (RLS), also named Willis-Ekbom disease, is a frequent neurological disease that is characterized by paresthesias and unpleasant sensations in the legs and an urge to move the legs $(1,2)$. These symptoms are usually aggravated during rest (3) and it disturbs sleep and impairs general health of patients with RLS (4). Ekbom (5) first defined RLS in 1945. After describing the diagnostic criteria by International Restless Legs Syndrome Study Group (IRLSSG), many epidemiological

Address for Correspondence/Yazışma Adresi: Gülnihal Kutlu MD, Muğla Sıtkı Koçman University Faculty of Medicine, Department of Neurology, Muğla, Turkey Phone: +90 5324173376 E-mail: gulnihalkutlu@yahoo.com ORCID-ID: orcid.org/0000-0002-9325-4151 Received/Geliş Tarihi: 18.12.2017 Accepted/Kabul Tarihi: 28.03.2018

${ }^{\circ}$ Copyright 2018 by Turkish Sleep Medicine Society / Journal of Turkish Sleep Medicine published by Galenos Publishing House. It was presented as poster presentation with same authors order at $2^{\text {nd }}$ European Neurology Academy in Copenhagen - Denmark between 28 -31 May 
studies were published (6). The prevalence of RLS is varied from region to region. According to population-based studies using full standard diagnostic criteria, the prevalence was changed between $5-10 \%$ in Western countries (7), however this percentage was lower in Asian and African population $(3,7)$. The diagnosis based on new clinical criteria: symptoms occurring during periods of rest, such as sitting or lying down; symptoms relieved by movement; symptoms worse in the evening or night; and above features is not solely accounted for as symptoms primary to another medical or a behavioral condition (1). The efficiency of dopaminergic treatment in RLS was well defined. This relationship was firstly recognized by Akpinar (8). Anticonvulsant drugs such as gabapentine and pregabalin showed good efficacy (9). There were also few studies and case reports on other anticonvulsant drugs such as carbamezapine, valproic acid and LEV (10-15).

Levetiracetam (LEV) is an effective and broad-spectrum anticonvulsant drug that is used in partial as well as generalized epilepsies $(16,17)$. Some neuropharmacological studies recommend LEV in the treatment of RLS (15), neuropathic pain (18) and in some types of movement disorders (19). The aim of this study is to investigate the effects of LEV on RLS in patients with epilepsy.

\section{Materials and Methods}

Two neurologists reviewed the files of 1680 patients retrospectively, who were followed up in Muğla Sıtkı Koçman University Faculty of Medicine and Antalya Training and Research Hospital Outpatient Epilepsy Department. One hundred twenty-nine patients, who took LEV monotherapy for at least 6 months, were called by telephone between January and February 2016. Twenty-two patients were not included in this study: We could not reach eighteen patients by phone. Four patients were excluded from the study because of diseases that may cause or aggravate RLS (one patient with Crohn disease, one patient with pregnancy, and two patients with diabetes mellitus). Therefore, one hundred seven patients under LEV monotherapy for at least 6 months and one hundred twenty healthy subjects were included in this study. The approval was obtained from Clinical Researches Ethics Committee of Muğla Sıtkı Koçman University (no: 2016/07).

The Turkish version of criteria suggested by the IRLSSG (1) was used in the evaluation for RLS (Table 1). Age, sex, detailed medical history, types of seizure and epilepsy, seizure frequency, duration of epilepsy, LEV dosage, electroencephalography (EEG) and neuroimaging findings, and the presence of RLS before and after LEV monotherapy were recorded for each patient. Biochemical parameters including blood glucose, hepatic and renal function test, iron, ferritin, vitamin B12, folic acid, thyroid function tests and electromyography (EMG) were performed both to patients and healthy subjects with RLS.

\section{Statistical Analysis}

Statistical analysis was carried out using IBM Statistical Package for Social Sciences (IBM SPSS Version 20.0 for Mac OS; SPSS, USA). Independent-sample t-tests and chi-square test were used statistically, and $p$ values equal to or less than 0.05 were accepted as statistically significant.

\section{Results}

One hundred seven patients and one hundred twenty healthy subjects were evaluated. The mean age of patient group was $38.26 \pm 17.39$ years (age range: $18-81$ years), while the mean age of healthy subjects was $39.17 \pm 16.12$ years (age range: 18-78 years). In patient group, 47 (43.9\%) were females, the remaining (60 patients, $56.1 \%)$ were males. Sixty-three $(52.5 \%)$ male and $57(47.5 \%)$ female subjects were present in control group. There were no statistically significant differences in terms of age $(p>0.05)$ and sex $(p>0.05)$ between patient's groups and healthy subjects.

\begin{tabular}{|l|}
\hline Table 1. Diagnostic criteria for Restless Legs syndrome according to International Restless Legs Syndrome Study Group (1) \\
\hline Essential diagnostic criteria \\
\hline 1. An urge to move the legs usually but not always accompanied by, or felt to be caused by, uncomfortable and unpleasant sensations in the legs \\
\hline $\begin{array}{l}\text { 2. The urge to move the legs and any accompanying unpleasant sensations begin or worsen during periods of rest or inactivity such as lying } \\
\text { down or sitting }\end{array}$ \\
\hline $\begin{array}{l}\text { 3. The urge to move the legs and any accompanying unpleasant sensations are partially or totally relieved by movement, } \\
\text { such as walking or stretching, at least as long as the activity continues }\end{array}$ \\
\hline $\begin{array}{l}\text { 4. The urge to move the legs and any accompanying unpleasant sensations during rest or inactivity only occur or are worse in the evening or night } \\
\text { than during the day }\end{array}$ \\
\hline $\begin{array}{l}\text { 5. The occurrence of the above features is not solely accounted for as symptoms primary to another medical or a behavioral condition } \\
\text { (e.g. myalgia, venous stasis, leg edema, arthritis, leg cramps, positional discomfort, habitual foot tapping) }\end{array}$ \\
\hline Specifiers for clinical course of Restless Legs syndrome/Willis-Ekbom disease \\
\hline A. Chronic-persistent RLS/WED: symptoms when not treated would occur on average at least twice weekly for the past year \\
\hline B. Intermittent RLS/WED: symptoms when not treated would occur on average <2/week for the past year, with at least five lifetime events \\
\hline Specifier for clinical significance of Restless Legs syndrome/Willis-Ekbom disease \\
\hline $\begin{array}{l}\text { The symptoms of RLS/WED cause significant distress or impairment in social, occupational, educational or other important areas of functioning } \\
\text { by their impact on }\end{array}$ \\
\hline Sleep, energy/vitality, daily activities, behavior, cognition or mood \\
\hline RLS: Restless Legs syndrome, WED: Willis-Ekbom disease \\
\hline
\end{tabular}


Kutlu et al.

Levetiracetam and Restless Legs Syndrome

\begin{tabular}{|l|l|l|l|l|l|l|}
\hline \multicolumn{7}{|l|}{ Table 2. Features of patients with Restless Leg syndrome in patient group } \\
\hline Age & Sex & Epilepsy & Seizure & Seizure & Epilepsy & LEV \\
\hline & & Duration & Frequency & Type & Syndrome & Dosage \\
\hline 60 yeras & M & 50 years & $10 /$ year & CPS & ExTLE & $2000 \mathrm{mg}$ \\
\hline 20 years & F & 4 years & $1 /$ year & Myoklonic & JME & $500 \mathrm{mg}$ \\
\hline 24 years & F & 2 years & Seizure free & Unclassified & - & $3000 \mathrm{mg}$ \\
\hline 25 years & M & 10 years & $1 /$ year & CPS & TLE & $2000 \mathrm{mg}$ \\
\hline M: Male, F: Female, CPS: Complex partial seizure, ExTLE: Extratemproral lobe epilepsy, JME: Jvenile myoclonic epilepsy, TLE: Temporal lobe epilepsy, LEV: Levetiracetam \\
\hline
\end{tabular}

There were no risk factors for epilepsy in 73 (68.2\%) patients. Head trauma was the most common risk factor (13 patients, $12.1 \%)$. The other risk factors were as follows: stroke (6 patients), tumor (3 patients), mental retardation (3 patients), febrile convulsion ( 3 patients), hypoxia during birth ( 3 patients), vascular abnormalities ( 2 patients), and central nervous system infection (1 patient). Seventeen patients (15.9\%) had a positive family history for epilepsy. Seventy-nine patients (73.8\%) had partial onset epilepsy, whereas idiopathic generalized epilepsy was detected in twenty-one patients. We could not classify the type of seizure and syndrome in seven patients (20). The most common epilepsy syndrome in patient group was temporal lobe epilepsy (46 patients, 43\%) followed by extra-temporal lobe epilepsy (33 patients, 30.8\%), juvenile myoclonic epilepsy (9 patients), juvenile absence epilepsy (5 patients) and epilepsy with grand mal seizure on awakening (7 patients) (21).

Fifty patients (46.7\%) had normal EEG. Focal epileptiform discharges were seen in 40 (37.4\%) patients followed by generalized epileptiform discharges in 12 patients. Focal or generalized slow waves were also observed in remaining 5 (4.7\%) patients. One hundred five patients (98.1\%) underwent neuroimaging (computerized tomography and/or magnetic resonance imaging). Seventy patients (65.4\%) had normal neuroimaging. The abnormalities of neuroimaging were as follows: encephalomalacia (11 patients), nonspecific ischemic gliotic region (9 patients), tumor (6 patients), hippocampal sclerosis (5 patients), brain atrophy (3 patients), encephalocele (1 patient). The frequency of seizure was between 0-120/year (mean frequency: $3.15 \pm 1.24 /$ year). Eighty-five patients (79.5\%) had $\leq 1$ seizures in a year. Only one patient had approximately 120 simple partial seizures in a year. The duration of epilepsy was 6-600 months (mean duration: 79.88 99.13 months).

All patients were using LEV for at least six months. The mean duration of LEV therapy was $28.34 \pm 2.32$ months (range: 6-120 months). The dosage of LEV was between $500-3000 \mathrm{mg} /$ day and the mean dosage was $1413.55 \pm 63.08 \mathrm{mg} /$ day.

RLS was observed in 7 (5.83\%) healthy subjects, whereas four patients $(3.73 \%)$ had RLS in the patient group before LEV treatment according to the IRLSSG criteria. There was no statistically significant difference between patient before LEV treatment and control group ( $p>0.05)$, although the ratio of RLS was quite different.

The symptoms of RLS was disappeared in two patients after the initiation of LEV treatment $(2000 \mathrm{mg} /$ day and $3000 \mathrm{mg} /$ day) after the beginning of LEV. The biochemical parameters and EMG were normal in these two patients. However, the complaints were continued after LEV treatment in other two patients. One of them had juvenile myoclonic epilepsy and took LEV therapy in a dose of $500 \mathrm{mg} /$ day. Biochemical parameters and EMG was normal in this patient. The other patient was using LEV therapy in a dose of $2000 \mathrm{mg} /$ day. There was no change in his RLS symptoms after LEV treatment. The biochemical parameters were also normal in that patient, but EMG revealed mild sensorimotor peripheral neuropathy. In summary, after LEV treatment, the symptoms of RLS disappeared in $50 \%$ of patients and the frequency of RLS decreased to $1.87 \%$. Table 2 shows the features of patients with RLS. There was no relation between the frequency of RLS and epilepsy duration, seizure frequency, type of seizure or epilepsy. In control group, EMG was normal in all patients. Biochemical parameters were examined only six patients who had RLS and they were normal. One patient had mild iron deficiency.

\section{Discussion}

RLS, a common movement disorder, is affecting the sleep and quality of life. There are many epidemiological studies to determine the prevalence of disease. The results of these studies show differences from each other according to the various part of the world (22). According to another study, only women participants were investigated, RLS prevalence was reported as $15.6 \%$ and mean age was 44.4 years. The prevalence was shown to increase by age (23). Another report showed that $8.4 \%$ of participants, who were $30-60$ years old, had RLS (24). The frequency of RLS is reported to be lower in Asian and African population. The frequency of RLS was $0.47 \%$ in one report from Tanzania (3) and $1.4 \%$ in one article from China (25).

Many epidemiological studies from different parts of Turkey were also published. RLS was observed as 3.19\%, 4.5\%, 7\% and $3.4 \%$ in reports from Mersin (southern part of country) (26), Trabzon (northeast Black Sea Region of Turkey) (27), Edirne (Western part of Turkey) (28) and Kandira (Western Black Sea coast) (7) respectively. Interestingly, the highest ratio for RLS was observed in Edirne, the northwest part of the Turkey. Muğla and Antalya is neighboring cities and located in Southern coast of Aegean Sea and West Mediterranean Sea. The frequency of RLS was $5.8 \%$ in aged-sex matched healthy subjects in this study.

Dopaminergic agents are the gold standard treatment of RLS $(4,29)$. Few small studies also reported the beneficial effects of antiepileptic drugs. There is not sufficient study showing the benefit of LEV in RLS management. The mechanism of LEV is not fully understood. It has been demonstrated that the synaptic vesicle protein SV2A is the brain binding side of LEV. It may be also useful in the treatment of neuropathic pain and 
in reducing L-Dopa induced dyskinesia (15). The first study that was included 20 patients with RLS, found that LEV does not appear to have a useful effect on the symptoms of RLS. Mean RLS severity score and sleep parameters in polysomnography was not changed after treatment (30). Della Marca et al. (15) reported two patients who had benefit from LEV treatment in terms of RLS symptomatology. Both of these patients had used dopaminergic agents but they had had no response. LEV therapy had then given to these patients with a dose of 1000 $\mathrm{mg} /$ day and satisfactory control of symptoms was observed. The authors suggested that LEV was a good therapeutic option in the treatment of RLS unresponsive to dopaminergic agents. Some patients develop tolerance to many drugs, while the therapeutic efficacy of LEV after two years of treatment was known to be long lasting.

RLS was reported to be more common in children with attention deficit hyperactivity disorder (ADHD). Epileptic seizures and EEG abnormalities were also seen frequently in these children. Therefore, comorbidity between ADHD, RLS, epileptic seizures and EEG abnormalities are common in clinical practice. In one study, LEV was given to children with RLS, who also had interictal epileptiform discharges. After LEV treatment, significant improvements both in International RLS rating scale and in EEG abnormalities were observed. The authors concluded that LEV could be a good option in patients with comorbid conditions such as ADHD, RLS and interictal EEG abnormalities (31).

\section{Conclusion}

In our study, the frequency of RLS was $5.8 \%$ in age-sex matched healthy subjects and $3.73 \%$ in patients with epilepsy under LEV monotherapy. This difference was not statistically significant, however, RLS was seen more frequent among healthy subjects. In patient group, four patients had RLS before LEV treatment. The symptoms of two patients were resolved completely after LEV $2000 \mathrm{mg} /$ day and $3000 \mathrm{mg} /$ day. The frequency of RLS was decreased to $1.87 \%$ after LEV treatment. Higher dosage of LEV (2000 mg/day and $3000 \mathrm{mg} /$ day) was observed to relieve RLS symptoms in these two patients. We therefore conclude that, in the presence of epilepsy and RLS comorbidity, LEV may be an effective choice of treatment. Further longitudinal and prospective studies are needed to confirm the therapeutic effects of LEV on RLS.

\section{Ethics}

Ethics Committee Approval: The approval was obtained from Clinical Researches Ethics Committee of Muğla Sıtkı Koçman University (approval no: 2016/07).

Informed Consent: It was taken.

Peer-review: Externally and internally peer-reviewed.

\section{Authorship Contributions}

Surgical and Medical Practices: G.K., A.E., F.G., Y.B.G., Y.Ü., D.A.Ö., Concept: G.K., Desing: G.K.,

Data Collection or Processing: F.G., Y.Ü., D.A.Ö., Y.B.G., G.K., Analysis or Interpretation: G.K., Y.B.G., Literature Search: G.K., Y.Ü., Writing: G.K.

Conflict of Interest: No conflict of interest was declared by the authors.
Financial Disclosure: The authors declared that this study received no financial support.

\section{References}

1. Allen RP, Picchietti DL, Garcia-Borreguero D, Ondo WG, Walters AS, Winkelman JW, Zucconi M, Ferri R, Trenkwalder C, Lee HB; International Restless Legss Syndrome Study Group. Restless legs syndrome/Willis-Ekbom diseasediagnostic criteria: updated International Restless Legss SyndromeStudy Group (IRLSSG) consensus criteria--history, rationale, description, and significance. Sleep Med 2014;15:860-73.

2. Tunc T, Karadag YS, Dogulu F, Inan LE. Predisposing factors of restless legs syndrome during pregnancy. Mov Disord 2007;22:627-31.

3. Burtscher C, Baxmann A, Kassubek J, Hornyak M, Matuja W, Schmutzhard E, Winkler AS. Prevalence of restless legs syndrome in an urban population of eastern Africa (Tanzania). J Neurol Sci 2014;346:121-7.

4. Sevim S, Dogu O, Kaleağası H, Aral M, Metin O, Camdeviren H. Correlation anxiety and depression symptoms in patients with restless legs syndrome: a population based survey. I Neurol Neurosurg Psychiatry 2014;75:226-30.

5. Ekbom KA. Restless legs. Acta Med Scand 1945;158:1-123

6. Walters AS. The International Restless Legs Syndrome Study Group. Toward a better definition of the restless legs syndrome. Mov Disord 1995; 10:634-42.

7. Taşdemir M, Erdoğan H, Börü UT, Dilaver E, Kumaş A. Epidemiology of restless legs syndrome in Turkish adults on the western Black Sea coast of Turkey: A door-to-door study in a rural area. Sleep Med 2010;11:82-6.

8. Akpinar S. Treatment of Restless legs syndrome with L-Dopa benseraside. Arch Neurol 1982;39:739.

9. Iftikhar IH, Alghothani L, Trotti LM. Gabapentin enacarbil, pregabalin and rotigotine are equally effective in restless legs syndrome: a comparative meta-analysis. Eur J Neurol 2017;24:1446-56.

10. Conti CF, Oliveira MM, Valbuza JS, Prado LB, Carvalho LB, Prado GF. Anticonvulsants to treat idiopathic restless legs syndrome: systematic review. ArqNeuropsiquiatr 2008;66(2B):431-5.

11. Telstad W, Sørensen O, Larsen S, Lillevold PE, Stensrud P, NybergHansen R. Treatment of the restless legs syndrome withcarbamazepine: a double blind study. Br Med J (Clin Res Ed) 1984;288:444-6.

12. Lundvall $\mathrm{O}$, Abom PE, Holm R. Carbamazepine in restless legs. A controlled pilot study. Eur J Clin Pharmacol 1983;25:323-4.

13. Eisensehr I, Ehrenberg BL, Rogge Solti S, Noachtar S. Treatment of idiopathic restless legs syndrome (RLS) with slow-release valproic acid compared with slow-release levodopa/benserazid. I Neurol 2004;251:579-83.

14. Kocaturk M, Kutlu G, Kocaturk O, Erdal A, Inan LE. Restless Legs Syndrome Among the Epilepsy Patients who Took Carbamazepine or Valproic Acid Monotherapy. Epilepsy 2013;19:58-62.

15. Della Marca G, Vollono C, Mariotti P, Mazza M, Mennuni GF, Tonali P, Mazza S. Levetiracetam can be effective in the treatment of restless legs syndrome with periodic limb movements in sleep: report of two cases. J NeurolNeurosurg Psychiatry 2006;77:566-7.

16. Jain KK. An assessment of levetiracetam as an anti-epileptic drug. Expert Opin Investig Drugs 2000;9:1611-24.

17. Kutlu G, Gomceli YB, Unal Y, Inan LE. Levetiracetam monotherapy for late poststroke seizures in the elderly. Epilepsy Behav 2008;13:542-4.

18. Enggaard TP, Klitgaard NA, Sindrup SH. Specific effect of levetiracetam in experimental human pain models. Eur J Pain 2006;10:193-8. 
19. Zesiewicz TA, Sullivan KL, Maldonado JL, Tatum WO, Hauser RA. Open-label pilot study of levetiracetam for the treatment of levodopa-induced dyskinesiasin Parkinson's disease. Mov Disord 2005;20:1205-9.

20. Commission on Classification and Terminology of the International League Against Epilepsy. Proposal for revised clinical and electrographic classification of epileptic seizures. Epilepsia 1981;22:489-501.

21. Commission on Classification and Terminology of the International League Against Epilepsy. Proposal for Revised Classification of Epilepsies and Epileptic Syndromes. Epilepsia 1989;30:389-99.

22. Allen RP, Walters AS, Montplaisir J, Hening W, Myers A, Bell TJ, FeriniStrambi L. Restless legs syndrome prevalence and impact: REST general population study. Arch Intern Med 2005;165:1286-92.

23. Lajous M, Kurth T, Catzin-Kuhlmann A, Romieu I, Lopez-Ridaura R. Prevalence of restless legs syndrome in 69,830 Mexican women. Rev Invest Clin 2014;66:303-6.

24. Wali SO, Abaalkhail B. Prevalence of restless legs syndrome and associated risk factors among middle-aged Saudi population. Ann Thorac Med 2015;10:193-8.

25. Shi $Y, Y u$ H, Ding D, Yu P, Wu D, Hong Z. Prevalence and risk factors of restless legs syndrome among Chinese adults in a rural community of Shanghai in China. PLoS One 2015;10:e0121215.
26. Sevim S, Dogu O, Camdeviren H, Bugdayci R, Sasmaz T, Kaleagasi $H$, Aral M, Helvaci I. Unexpectedly low prevalence and unusual characteristics of RLS in Mersin, Turkey. Neurology 2003;61:1562-9.

27. Altunayoglu Cakmak V, Koc B, Nuhoglu I, Topbas M, Ucuncu SY, Deger O, Kamburoglu S, Velioglu S. Prevalence of restless legs syndrome in Trabzon in the northeast Black Sea Region of Turkey: co-morbidities, socioeconomic factors and biochemical parameters. Neurol Res 2015;37:751-62.

28. Güler S, Caylan A, Nesrin Turan F, Dağdeviren N, Çelik Y. The prevalence of restless legs syndrome in Edirne and its districts concomitant comorbid conditions and secondary complications. Neurol Sci 2015;36:1805-12.

29. Byrne R, Sinha S, Chaudhuri KR. Restless legs syndrome: diagnosis and review of management options. Neuropsychiatr Dis Treat 2006;2:155-64.

30. UCB 2006. Efficacy and tolerability of levetiracetam in the treatment of restless legs syndrome: a double-blind placebo controlled crossover trial. Presentedat the meeting of the American Neurological Association; 2006.

31. Gagliano A, Arico I, Calarese T, Condurso R, Germano E, Cedro C, Spina E, Silvestri R. Restless Legs Syndrome in ADHD children: levetiracetam as a reasonable therapeutic option. Brain Dev 2011;33:480-6. 